\title{
Temporal Evolution of the Barombi Mbo Maar, a Polygenetic Maar-Diatreme Volcano of the Cameroon Volcanic Line*
}

\author{
Boris Chako Tchamabé1\#, Takeshi Ohba ${ }^{1}$, Issa ${ }^{1}$, Seigo Ooki ${ }^{1}$, Dieudonné Youmen ${ }^{2}$, \\ Sebastien Owona ${ }^{2}$, Gregory Tanyileke ${ }^{3}$, Joseph Victor Hell ${ }^{3}$ \\ ${ }^{1}$ Laboratory of Volcanology and Geochemistry, Department of Chemistry, Tokai University, Tokyo, Japan \\ ${ }^{2}$ Department of Earth Science, Faculty of Sciences, University of Douala, Douala, Cameroon \\ ${ }^{3}$ Institute of Mining and Geological Research (IRGM), Yaoundé, Cameroon \\ Email: " boris.chako@yahoo.fr
}

Received 1 August 2014; revised 25 August 2014; accepted 15 September 2014

Copyright (C) 2014 by authors and Scientific Research Publishing Inc.

This work is licensed under the Creative Commons Attribution International License (CC BY). http://creativecommons.org/licenses/by/4.0/

c) (i) Open Access

\begin{abstract}
The Barombi Mbo Maar (BMM), which is the largest maar in Cameroon, possesses about 126 mthick well-preserved pyroclastic deposits sequence in which two successive paleosoil beds have been identified. The maar was thought to have been active a million years ago. However, layers stratigraphically separated by the identified paleosoils have been dated to shed lights on its age and to reconstruct the chronology of its past activity. The results showed that the BMM formed through three eruptive cycles: the first $\sim 0.51 \mathrm{Ma}$ ago, the second at $\sim 0.2 \mathrm{Ma}$ and the third $\sim 0.08 \mathrm{Ma}$ B.P. The ages indicate that the BMM maar-forming eruptions were younger than a million years. The findings also suggested that the maar is polygenetic. At a regional scale, the eruptive events would have occurred during some volcanic manifestations at Mt Manengouba and Mt Cameroon. Therefore, with the decrease in the recurrence time of eruptions from $0.3 \mathrm{Ma}$ to $0.1 \mathrm{Ma}$, and given the possible relation between its eruptive events and those of its neighboring polygenetic volcanoes, the BMM is expected to erupt within the next $20 \mathrm{ka}$.
\end{abstract}

\section{Keywords}

Maar, Eruptive Episodes, Barombi Mbo, Cameroon

\footnotetext{
*Insight into polycyclic activity at the Barombi Mbo Maar.

${ }^{*}$ Corresponding author.
}

How to cite this paper: Chako Tchamabé, B., Ohba, T., Issa, Ooki, S., Youmen, D., Owona, S., Tanyileke, G. and Hell, J.V. (2014) Temporal Evolution of the Barombi Mbo Maar, a Polygenetic Maar-Diatreme Volcano of the Cameroon Volcanic Line. International Journal of Geosciences, 5, 1315-1323. http://dx.doi.org/10.4236/ijg.2014.511108 


\section{Introduction}

Maar-diatreme volcanoes are created by many sub-surface phreatomagmatic explosions, which occur when magma interacts with groundwater/water saturated sediments [1] [2]. However, due to variations in magma and local water abundance and fluxes, intermittent Strombolian, lava-fountaining and/or effusive activities can also develop within the eruption progression. Typical maars are known to be monogenetic volcanoes [2], with eruptions lasting from hours to up to weeks [3]. However, when closely examined, the contrasting volcanic facies presented by their deposits in addition to the presence of erosional limits such as paleosol suggest that some maars result from multiple eruptive events separated by significant quiescence periods of thousands of years. Such maars, interpreted as polygenetic, have been little documented. Case examples are the Gölcük maar volcano in Turkey [4], the Albano Maar in Italy [5], or the Hule Maar in Costa Rica [6].

In this study, we present the case of the Barombi Mbo Maar (BMM) located in the Kumba Volcanic Field, in the South-West Region of Cameroon (Figure 1). Recently, from a tephrostratigraphic examination, the about

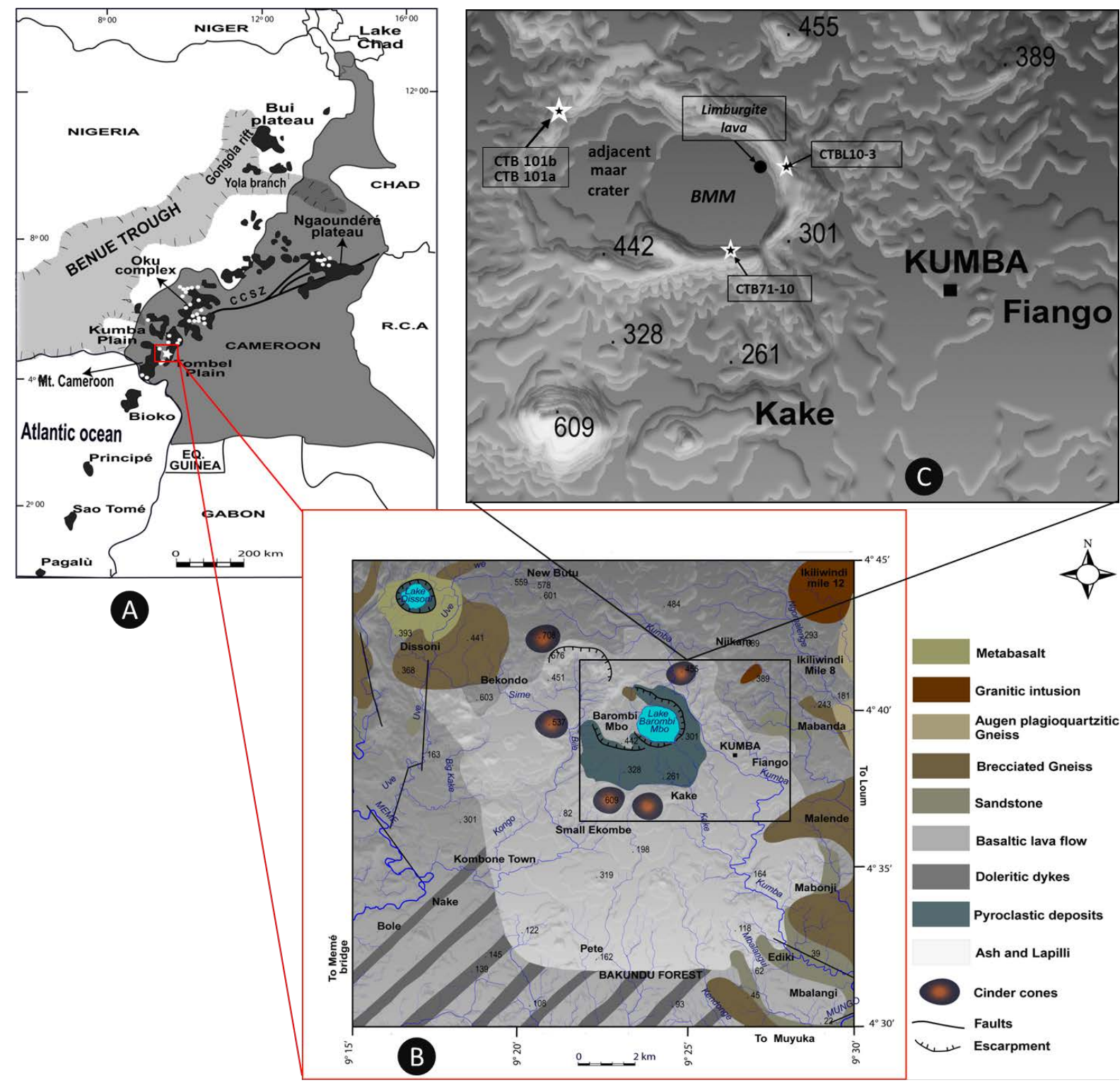

Figure 1. Location map of the study area along the Cameroon volcanic line (A) and the geological map (B), modified after [7]. (C) shows the sampling points (stars) around the BMM and the adjacent maar, and the position of the limburgitic lava flow (black dot). 
126 m-thick tephra pile preserved at its eastern flank was subdivided into three stratigraphic units $U_{1}, U_{2}$ and $U_{3}$ [7]. The first unit $\left(\mathrm{U}_{1}\right)$ consists of about $26 \mathrm{~m}$-thick series of alternating unconsolidated and consolidated sets of thinly and well-stratified lapilli- and ash-beds. The second unit $\left(\mathrm{U}_{2}\right)$, which is about $12 \mathrm{~m}$-thick, consists of a scoria-rich layer containing various centimeter- to decimeter-sized spatter bombs, vesiculated scoria, few mantle xenoliths and country rocks; a lithic and mantle xenolith rich-explosive breccia; and two compact and consolidated layers of lapillituff and lapillistone. The upper unit $U_{3}$ comprises fallout and pyroclastic density current derived-beds piled up repetitively for about $90 \mathrm{~m}$. Units $\mathrm{U}_{1}$ and $\mathrm{U}_{2}$ were thought to have been deposited during a volcanic episode that initiated the BMM formation [7]. A well-distinct $10 \mathrm{~cm}$-thick paleosoil bed, which is indicative of relatively long quiescent period, separates the precedent units from the upper unit $U_{3}$. From those observations, it was suggested that the BMM might be a polygenetic maar [7]. However, no systematic geochronological evidence existed to comfort that observation. For instance, the first age to be published for the BMM was $1 \mathrm{Ma}$ [8] and was obtained from a prismatic lava flow cropping at the eastern shore of the BMM crater (Figure 1(C)). This age was interpreted to be that of the likely last eruptive event of the BMM [8]. Two other ages of 0.20 and 0.24 Ma were obtained on two lherzolite bearing trachy-basalts collected in the BMM pyroclastic sequence [9]. Although those young (relative to the $1 \mathrm{Ma}$ ) ages clearly suggest that volcanic activities at the BMM were more recent, they do not say anything about either the first or the last eruptive phase on the BMM or even on its potential polygenetic nature [7]. Moreover, during a recent field investigation, another likely poorly developed soil-bed was identified in the upper part of the BMM's pyroclastic deposits sequence [Chako Tchamabé, personal communication], implying that the eruptive history of the BMM could be more complex than previously thought [7]. Therefore, it is important to investigate the chronologic relationship between the prismatic lava flow and the different maar-forming eruptive events. This study aims at clarifying that issue, in order to appreciate the temporal evolution of the BMM, and shed lights on its polygenetic nature. To this end, we carried out additional K-Ar dating of samples collected from both the BMM and the western adjacent maar deposits (Figure 1(C)). The selection of samples in the BMM pyroclastic deposits was guided by the stratigraphic location of the identified paleosoils.

\section{Geological Outline of the BMM}

The BMM is a large maar crater ( 2.5 km in diameter) occupied by a lake, namely Lake Barombi Mbo. As pointed out in the introduction, the pyroclastic materials surrounding the lake were emplaced by a complex eruptive sequence consisting of at least two eruptive cycles.

The proxy-geology of the BMM is still poorly known. However, based on the composite fragments contained in its pyroclastic deposits, it is likely that the maar cuts through a geological succession composed by granitegneissic formation, sandstones, and basaltic lava flows; the same formations that make up the Kumba volcanic field [10]-[12]. The volcanic activity in the volcanic field began probably in the Eocene as at other volcanic centers along the Cameroon Volcanic Line [12]. However, there is no information about the age of latest volcanic activities there.

\section{Sampling, Sample Preparation and Dating Methodology}

\subsection{Sampling Strategy}

A total of five fresh juvenile rocks, with very few crustal xenoliths were collected and dated. These include two samples CTB71-10 from $\mathrm{U}_{2}$ and CTBL10-3 from the upper most layers of unit $\mathrm{U}_{3}$. The sample CTBL10-3 was collected at the uppermost part of $\mathrm{U}_{3}$ so as to have an age representative and close as possible to the final stage of activities. This sampling strategy was also done to further check if the difference between the obtained ages could fit a minimum time necessary to the formation of the different soil beds mentioned above. Two other samples (CTBa101a and CTB101b) were collected from the deposits of the western adjacent maar (Figure 1(C)) in order to check its relationship to the BMM evolution. The last sample (CTB124a) was taken at the summit of the strombolian islet of the Kotto Barombi Maar. This islet was presented as the final eruptive stage at that volcano [10]. Therefore, its age could also be important for comparison with the BMM eruptions.

Prior to K-Ar dating process, the samples were assured for their freshness. Thin sections were thus prepared and checked for the degree of alteration. The samples present a micro-porphyritic texture and characterized by the presence of millimeter-sized crystals of plagioclases, olivine, pyroxenes, and micas, embedded in a micro- 
crystalline groundmass. No sign of significant alteration was observed, except the slight oxidation around some vesicles of CTBL10-3 (Figure 2).

\subsection{K-Ar Dating: Mineral Separation, Quantification of Potassium Contents and Argon Isotope Ratios}

Whole-rock K-Ar dating was carried out commercially by the Hiruzen Institute for Geology and Chronology, Japan. Sample preparation was done according to the procedures described in [13]. The procedure consists of slicing of rock samples into thin plate shape of about $5 \mathrm{~mm}-1 \mathrm{~cm}$ thickness. By doing so, it is possible to remove much of the heterogeneous and weathered rock fragments and minerals specimen especially phenocrysts and xenocrysts, which are potential carriers of extraneous ${ }^{40} \mathrm{Ar}$ (including excess and inherited components) from the samples. A homogeneous part of the sample is then crushed in a stamp mill and sieved to 60 - 80 mesh size. The aliquot is ultrasonically washed several times with deionized water and dried up. Then, a hand magnet is used to remove the magnetic minerals, and the sample is resized again to 60 - 80 mesh size. After this stage, an electromagnetic separator is used to remove the ferromagnetic phenocrysts, and the sample undergoes another ultrasonic bath cleaning. The process is deemed to increase the $\mathrm{K}$ content as well as the percentage of radiogenic argon over the bulk rock values. It also minimizes the potential sources of systematic error due to the presence of excess ${ }^{40} \mathrm{Ar}^{*}$.

Potassium contents were analyzed by flame spectroscopy on solution prepared from about $1 \mathrm{~g}$ of sample [14]. The analytical reproducibility was better than $2 \%$. Regarding the argon isotopes, the measurement was done at the Okayama University of Science, Japan, using an HIRU Mass spectrometer. The measurement method and

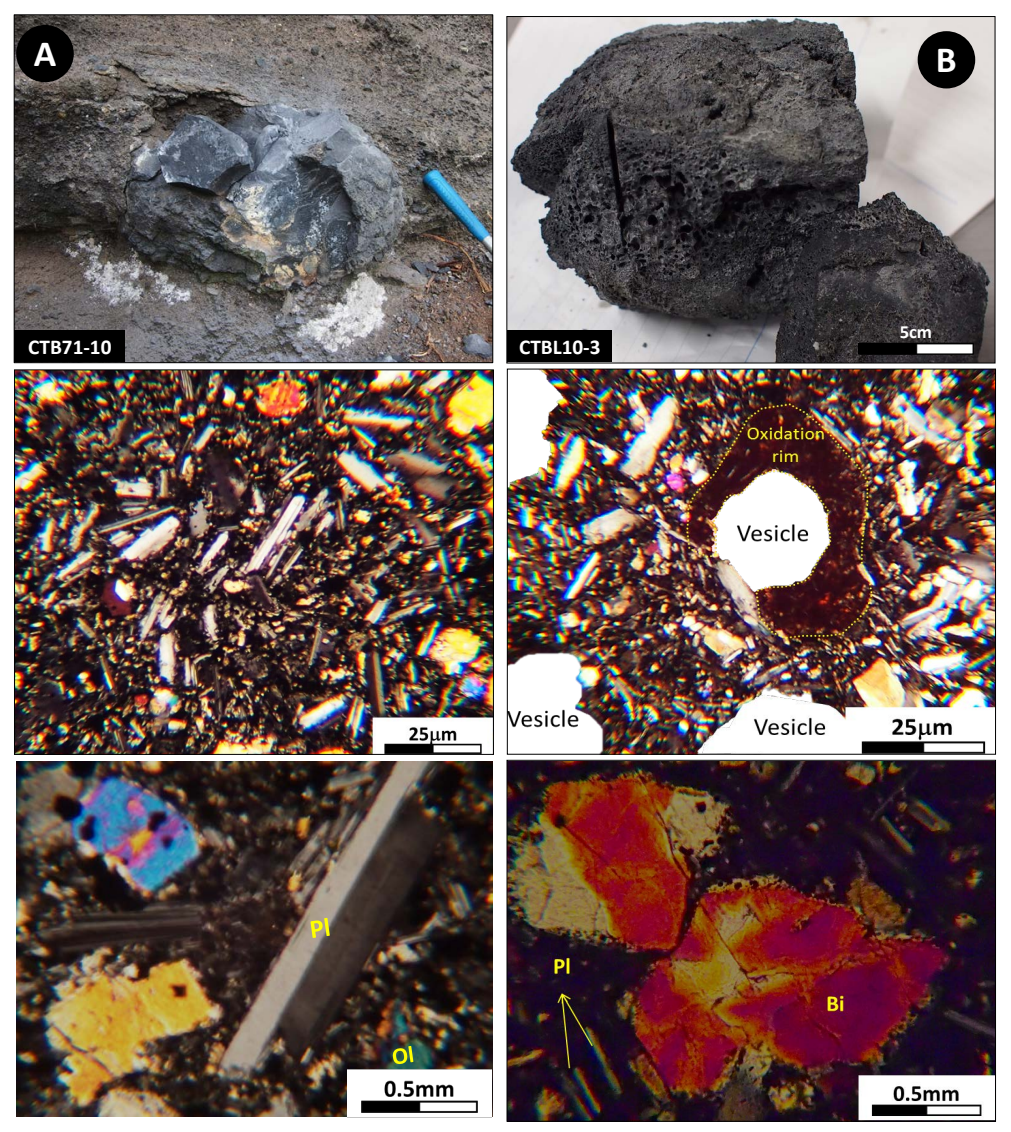

Figure 2. Photographs of the samples CTB71-10 and CTB-L10-3, showing their macroscopic bomb aspect on field. Each sample is shown with its thin sections images below it. It can be observed on the thin sections that the phenocrysts are not altered, confirming the freshness of the samples. Pl: Plagioclase; Bi: Biotite; Ol: Olivine. 
sample preparation are described in detail in [15]. For this study, a minimum of eight sets for ${ }^{38} \mathrm{Ar}$ and ${ }^{36} \mathrm{Ar}$, and seven sets for ${ }^{40} \mathrm{Ar}$ were measured, in order to overcome the memory effect within the Mass spectrometer. Age calculations were based on the decay and abundance constants from [16].

\section{Results and Discussion}

The chemical compositions of the dated samples are reported in (Table 1). The potassium contents, isotopic results and the obtained ages are reported in Table 2. The two samples collected from the BMM pyroclastic sequence, CTB71-10 from $U_{2}$ and CTBL10-3 from $U_{3}$ yielded ages of 0.5129 \pm 0.049 Ma and 0.0836 $\pm 0.073 \mathrm{Ma}$, respectively. Samples from the adjacent maar yielded ages of $0.29 \pm 0.04 \mathrm{Ma}$ for CTB101a and $0.34 \pm 0.01 \mathrm{Ma}$ for CTB101b. The other sample collected at Kotto Barombi (CTB124a) gave an age $0.05 \pm 0.01 \mathrm{Ma}$. Almost all the samples have ages with relatively good errors, except for sample CTBL10-3 $\left(\mathrm{U}_{3}\right)$ for which the error is almost close to the age. This error may be due to its high (98.18\%) non-radiogenic argon content (Table 1). For example, it was shown that, for a sample of less than $0.2 \mathrm{Ma}$, if the excess argon content is high (i.e., >97\%), it can significantly affect its K-Ar age [17]. Excess argon can originate from the initial magmatic argon trapped in (mainly phenocrystic) mineral fluid inclusions. Also, if there is insufficient magma degassing, which result to highly vesiculated lavas, samples of such lavas can have an important initial argon retention capacity. Therefore, such lavas can present high amounts of non-radiogenic argon, leading to large errors in ages. Thus, the high content in non-radiogenic argon for the CTBL10-3 that might be due to its vesiculated aspect (Figure 2(B)), can explain the large error obtained on its age. To further check the reliability of the $0.08 \pm 0.07$ Ma age of CTBL10-3, we compared it to the age of the 23 m-thick sediments cored in the BMM crater [18]. According to [18], the middle of those sediments was $\sim 0.021$ Ma B.P. The latter age might suggest a sedimentation rate of about 0.4 $\mathrm{mm} /$ year. However, after the formation of a maar, it should require a certain time for a catchment to develop and

Table 1. Chemical composition of the dated samples. These analytical results are from Chako Tchamabé (unpublished). Sample Limburgite (*) is the sample MBO.3 from [8], including 2.5\% L.O.I. and is presented here just for comparison.

\begin{tabular}{ccccccccccccc}
\hline Sample & $\mathrm{SiO}_{2}$ & $\mathrm{TiO}_{2}$ & $\mathrm{Al}_{2} \mathrm{O}_{3}$ & $\mathrm{~T}_{-} \mathrm{Fe}_{2} \mathrm{O}_{3}$ & $\mathrm{MnO}$ & $\mathrm{MgO}$ & $\mathrm{CaO}$ & $\mathrm{Na}_{2} \mathrm{O}$ & $\mathrm{K}_{2} \mathrm{O}$ & $\mathrm{P}_{2} \mathrm{O}_{5}$ & $\mathrm{Total}^{2}$ \\
\hline Limburgite & 41.70 & 3.41 & 13.58 & 15.12 & 0.18 & 9.41 & 11.41 & 1.45 & 1.89 & 1.31 & 99.46 \\
Limburgite (*) & 40.31 & 3.45 & 13.17 & 14.86 & 0.20 & 9.25 & 11.17 & 1.51 & 1.87 & 1.10 & 99.60 \\
CTB71-10 (Basalt) & 48.28 & 2.91 & 14.38 & 12.90 & 0.16 & 7.14 & 8.15 & 3.39 & 1.29 & 0.39 & 99.04 \\
CTBL10-3 (Basalt) & 46.56 & 5.65 & 14.01 & 14.21 & 0.15 & 6.82 & 7.44 & 3.37 & 1.13 & 0.20 & 99.54 \\
CTB124a (Basalt) & 45.63 & 3.01 & 14.76 & 12.71 & 0.20 & 7.26 & 10.80 & 3.70 & 1.51 & 0.41 & 100 \\
CTB101a (Basalt) & 45.97 & 3.60 & 15.33 & 14.14 & 0.18 & 7.17 & 8.53 & 3.22 & 1.23 & 0.63 & 100 \\
CTB101b (Basalt) & 45.93 & 3.50 & 15.12 & 13.79 & 0.18 & 7.17 & 8.92 & 3.39 & 1.36 & 0.64 & 100 \\
\hline
\end{tabular}

Table 2. K-Ar ages of samples from the BMM.

\begin{tabular}{|c|c|c|c|c|c|c|c|}
\hline Sample ID & $\begin{array}{c}\text { Weight } \\
\text { molten (g) }\end{array}$ & $\mathrm{K}(\mathrm{wt} \%)$ & {$\left[{ }^{36} \mathrm{Ar}\right]$ measured } & {$\left[{ }^{40} \mathrm{Ar}\right]$ measured } & $\begin{array}{c}{\left[{ }^{40} \mathrm{Ar}\right]_{\mathrm{rad}}} \\
\left(10^{-8} \mathrm{ccSTP} / \mathrm{g}\right)\end{array}$ & $\begin{array}{l}\text { Non-radiogenic } \\
{ }^{40} \text { Ar contents (\%) }\end{array}$ & K-Ar age (Ma) \\
\hline CTBL10-3 & 1.0069 & $1.140 \pm 0.023$ & $1.539 \mathrm{E}-12 \pm 4.827 \mathrm{E}-15$ & $3.628 \mathrm{E}-10 \pm 1.911 \mathrm{E}-13$ & $0.3700 \pm 0.3221$ & 98.18 & $0.0836 \pm 0.0728$ \\
\hline СТВ71-10 & 1.0038 & $1.133 \pm 0.023$ & $9.225 \mathrm{E}-13 \pm 6.044 \mathrm{E}-15$ & $2.564 \mathrm{E}-10 \pm 1.901 \mathrm{E}-13$ & $2.2552 \pm 0.2137$ & 84.36 & $0.5129 \pm 0.0497$ \\
\hline СТВ101a & 1.0267 & $0.984 \pm 0.020$ & $5.239 \mathrm{E}-13 \pm 2.643 \mathrm{E}-15$ & $1.450 \mathrm{E}-10 \pm 3.060 \mathrm{E}-13$ & $1.1140 \pm 0.1458$ & 88.3 & $0.2917 \pm 0.0386$ \\
\hline CTB101b & 1.0242 & $1.040 \pm 0.021$ & $2.417 \mathrm{E}-13 \pm 1.652 \mathrm{E}-15$ & $8.156 \mathrm{E}-11 \pm 1.683 \mathrm{E}-13$ & $1.3921 \pm 0.0783$ & 73.9 & $0.3449 \pm 0.0062$ \\
\hline СТВ124a & 1.0378 & $1.299 \pm 0.026$ & $2.965 \mathrm{E}-13 \pm 2.093 \mathrm{E}-15$ & $7.765 \mathrm{E}-11 \pm 4.487 \mathrm{E}-13$ & $0.2461 \pm 0.0820$ & 95.1 & $0.0488 \pm 0.01683$ \\
\hline \multirow{2}{*}{ Aka (2000) } & 0.4721 & $1.360 \pm 0.068$ & $6.336 \mathrm{E}-10 \pm 3.248 \mathrm{E}-11$ & $2.000 \mathrm{E}-07 \pm 1.312 \mathrm{E}-09$ & $1.2470 \pm 0.78$ & - & $0.24 \pm 0.02$ \\
\hline & 0.4716 & $1.430 \pm 0.071$ & $2.149 \mathrm{E}-10 \pm 1.265 \mathrm{E}-11$ & $7.479 \mathrm{E}-08 \pm 9.257 \mathrm{E}-10$ & $1.1180 \pm 0.76$ & - & $0.20 \pm 0.02$ \\
\hline
\end{tabular}


start to fill a maar crater with fluvial sediments. That time can be long depending on the climate and the hydrological system of the area where the maar is located. In the case of the BMM, the climate is of equatorial type, and the small size of its actual catchment is $\sim 8 \mathrm{~km}^{2}$ only and limited to the flat bottom of the old maar [8]. Given the large crater diameter $(\sim 2.5 \mathrm{~km})$ of the BMM and assuming a sedimentation rate of $0.4 \mathrm{~mm} /$ year, one can argue that the $23 \mathrm{~m}$-thick sediments would have deposited during the last $50 \mathrm{ka}$. This agrees with the $0.083 \mathrm{Ma}$ obtained for the youngest dated age at BMM. Taking into account all these observations, the obtained age for CTBL10-3 is acceptable. These findings confirm the observations that $U_{1}$ and $U_{2}$ on the one hand and $U_{3}$ on the other hand were deposited by distinct eruptive episodes [7]. One episode occurred $\sim 0.5 \mathrm{Ma}$ and another around $\sim 0.08 \mathrm{Ma}$ B.P. The findings, together with the 0.2 Ma obtained from [9] reveal that the eruption that putted in place the 1 Ma lava flow was not the final one as suggested by [8] but would rather correspond to an older activity around the BMM. However, the proximity of this lava to the BMM crater opens the question as to whether it was produced from the same vent or from an earlier activity. In fact, during the formation of maars, a small volume of the rising magma can follow a crack or any weakness in the substrate to reach the surface without interacting with groundwater [19]. In such case, a small lava flow and/or a scoria cones can form near maar vents depending on the degree of viscosity and the magma volume. It is likely that such phenomenon would have been responsible to the formation of the limburgitic lava flow, given its very small outcrop surface. However, its position close to the BMM crater requires that any post-eruption would have fragmented it. That might be why, judging from its smooth surface, it was thought that the lava was not fragmented by the BMM maar-forming eruptions [8], and hence concluding that the 1 Ma was probably that of the last eruptive event at the BMM. Although the smooth surface of the lava might orient to such conclusion, the fact that the lava is prismatic, its fragmentation can be quite easy. Also, the action of water that could polish the fragmented surface can give the impression that the lava was not fragmented. However, given all these incertitude, it is not easy to say whether or not the lava and the maar are volcanically linked based only on field observation. Nevertheless, it can be observed from our obtained ages that that lava flow pre-dated the BMM pyroclastic deposits. It even pre-dated the formation of the western adjacent maar where eruptions would have occurred between 0.29 Ma and 0.35 Ma B.P.

On the basis of the observations above, the temporal evolution of the BMM as summarized in Figure 3 can thus be described as follows: after the eruptive activity that produced the limburgitic lava flow about a million year ago, the first series of phreatomagmatic eruptions that probably initiated the formation of BMM started about 0.513 Ma B.P. These first series of eruptions were followed by the development of a paleosol on the tephra units. During this reposed time, a series of phreatomagmatic explosions occurred also at the western part of the BMM crater and resulted in the formation of the adjacent maar crater. This suggests that there was a lateral shift in the eruptive vents, which can be observed within the development of polycyclic volcanoes [20].

Then explosions restarted at the eastern part with a second series of phreatomagmatic eruptions. Judging from the 0.2 Ma age from [9], this second activity took place $\sim 0.2$ Ma ago, suggesting a repose period of about 0.3 Ma. This 0.3 Ma of repose time is in agreement with the minimum timescale (>thousands of years) during which a soil might form and evolve [21]. For example, soil layers found within the $80 \mathrm{~m}$-thick pyroclastic sequence of the Albano maar deposits took a same range of time i.e., $~ 0.3$ and $\sim 0.03 \mathrm{Ma}$ to form [5]. The eruptive activities might have resumed at the BMM $\sim 0.083$ Ma B.P. This age at the uppermost unit also suggests a volcanic hiatus of about $0.12 \mathrm{Ma}$, which is still in accordance with a minimum timescale necessary for a soil to form. It, therefore, confirms that the poorly developed soil bed is another paleosoil, implying that the BMM formed by three eruptive cycles. This confirms that the BMM is a polygenetic maar.

The present findings have implications on the regional volcanism. We observed, for example, that the first eruptive episode $(0.513 \mathrm{Ma}$ ) occurred at about the same time as the one that put in place the Eboga crater on the Mt Manengouba $\sim 0.56 \mathrm{Ma}$ ago [22]. Also, the second eruptive episode (0.2 Ma) took place during some fissural activities about $0.2 \mathrm{Ma}$ on that same volcano, which is located at $\sim 62 \mathrm{~km} \mathrm{NE}$ of BMM [22]. It also appears that most of the strombolian activities that produced cinder cones and others small lava flows composing the Tombel graben occurred within the last $0.1 \mathrm{Ma}$ [23]. The graben is the nearest monogenetic volcanic field to the Kumba volcanic field. In addition, [24] suggested that an eruption would have occurred at Mt Cameroon, located 60 $\mathrm{km}$ southwest the BMM, during the same period ( $0.1 \mathrm{Ma})$. These periods of strombolian activities in the Tombel graben and the eruption at the Mt Cameroon would have been also relatively contemporaneous to the final eruptive phase ( $\sim 0.08 \mathrm{Ma})$ at the BMM. Those observations suggest that the BMM would have formed during some intense volcanic manifestations of the Cameroon volcanic line. In addition, the youngest age obtained in this study $(0.05 \pm 0.02 \mathrm{Ma})$ was from the sample of the Barombi Kotto Maar. We suggest that this may represent 


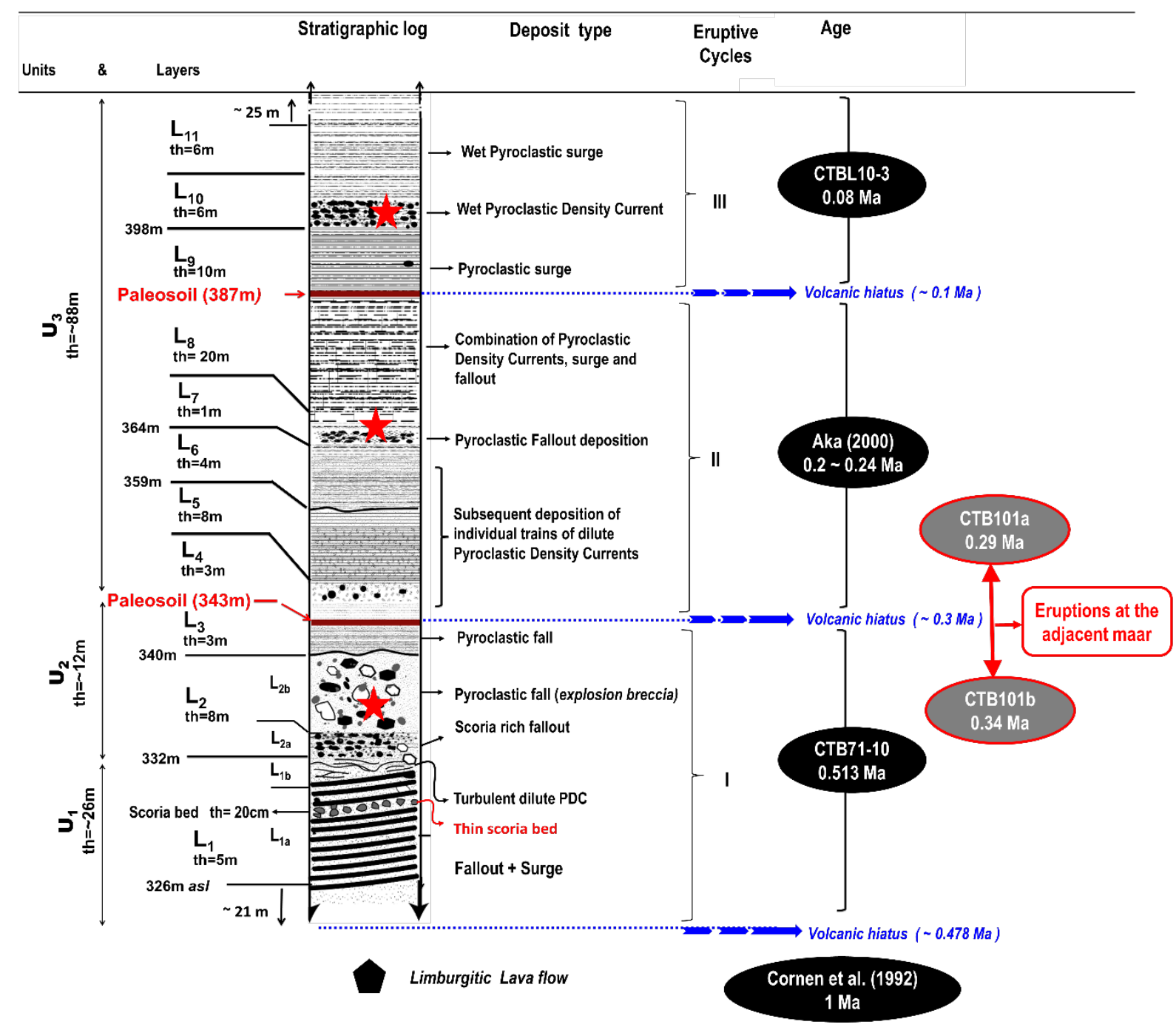

Figure 3. Schematic reconstruction of the chronology of eruptions at the BMM the stratigraphic log is modified after [7]. The red stars in the stratigraphic log represent the positions of the dated samples, and from the bottom to the top, we have sample CTB71-10, Sample from [9] and sample CTBL10-3.

the latest volcanic activity in the Kumba volcanic filed. This suggestion is corroborated by field observation that deposits in Kotto Barombi are relatively fresher than in Barombi Mbo.

For hazard purposes, the differences between the ages of the eruptive phases indicate that the eruption frequency within the BMM varied from $\sim 0.3$ to $0.1 \mathrm{Ma}$. If the concomitant eruptions observed signifies that the BMM activity might be related to those of its neighboring polygenetic volcanoes (Mt Cameroon and Mt Manengouba), it is likely that any future intense volcanic activity on these polygenetic volcanoes, could trigger another eruption at the BMM. Another issue is the evidence provided here for polycyclic behavior of BMM. The fact also that eruptions occurred almost at the same place and given that there would have been a renewal of explosions at the first eruptive site, the renewal potentiality at the other explosive site is also possible.

\section{Conclusion}

This study has shown that the recent activity of the BMM appears to be quite young, taking place in the Holocene. Activities would have begun $\sim 0.5 \mathrm{Ma}$ ago and resumed $\sim 0.08 \mathrm{Ma}$ ago rather than $1 \mathrm{Ma}$ ago. The study has permitted to confirm the existence of a second thin paleosoil bed throughout the deposits. This has straighten the two eruptive episodes indicated by [7] at three main eruptive cycles for the BMM. Those eruptive cycles, which 
highlight the polycyclic nature of the BMM, would have occurred during a general volcanism that affected the region. This included volcanic eruptions at the Mt Cameroon and mainly at the Mt Manengouba and in the Tombel graben. The recurrence time from an eruptive cycle to another appeared to diminish from $0.3 \mathrm{Ma}-0.1$ Ma. This decrease in the frequency of eruption suggests that the BMM can experience a volcanic activity at any time within the future $20 \mathrm{ka}$, especially if a high explosion occurs at the Mt Cameroon, which is still active.

\section{Acknowledgements}

This work was supported by the SATREPS-NyMo project, funded by Cameroon and Japan governments. Thorough review by Aka Festus T. and anonymous reviewers greatly improved the manuscript. Dr. Yagi of the Hiruzen Institute for Geology and Chronologyis thanked for the Age measurements. Tadjon T. Landry is acknowledged with thanks for the assistance of during field work.

\section{References}

[1] McClintock, M., White, J.D.L., Houghton, B.F. and Skilling, I.P. (2008) Physical Volcanology of a Large CraterComplex Formed during the Initial Stages of Karoo Flood Basalt Volcanism, Sterkspruit, Eastern Cape, South Africa. Journal of Volcanology and Geothermal Research, 172, 93-111. http://dx.doi.org/10.1016/j.jvolgeores.2005.11.012

[2] Walker, G.P.L. (2000) Basaltic Volcanoes and Volcanic Systems. In: Sigurdsson, H., Houghton, B., McNutt, S.R., Rymer, H. and Stix, J., Eds., Encyclopedia of Volcanoes, Academic Press, New York, 283-290.

[3] Lorenz, V. (2007) Syn- and Post-Eruptive Hazards of Maar-Diatreme Volcanoes. Journal of Volcanology and Geothermal Research, 159, 285-312. http://dx.doi.org/10.1016/j.jvolgeores.2006.02.015

[4] Platevoet, B., Scaillet, S., Guillou, H., Blamart, D., Nomade, S., Massault, M., Poisson, A., Elitok, Ö., Özgür, N., Yagmurlu, F. and Yilmaz, K. (2008) Pleistocene Eruptive Chronology of the GölcükVolcano, Isparta Angle, Turkey. Quaternaire, 19, 147-156. http://dx.doi.org/10.4000/quaternaire.3092

[5] Giaccio, B., Marra, F., Hajdas, I., Karner, D.B., Renne, P.R. and Sposato, A. (2009) ${ }^{40} \mathrm{Ar} /{ }^{39} \mathrm{Ar}$ and ${ }^{14} \mathrm{C}$ Geochronology of the Albano Maar Deposits: Implications for Defining the Age and Eruptive Style of the Most Recent Explosive Activity at ColliAlbani Volcanic District, Central Italy. Journal of Volcanology and Geothermal Research, 185, 203-213. http://dx.doi.org/10.1016/j.jvolgeores.2009.05.011

[6] Alvarado, G.E., Soto, G.J., Salani, F.M., Ruiz, P. and de Mendoza, L.H. (2010) The Formation and Evolution of Hule and Río Cuarto Maars, Costa Rica. Journal of Volcanology and Geothermal Research, 201, 342-356.

[7] Chako Tchamabé, B., Youmen, D., Owona, S., Issa, Ohba, T., Németh, K., Ngapna, M.N., Asaah, A.N.E., Aka, F.T., Tanyileke, G. and Hell, J.V. (2013) Eruptive history of the Barombi Mbo Maar, Cameroon Volcanic Line, Central Africa: Constrains from Volcanic Facies Analysis. Central European Journal of Geosciences, 5, 480-496. http://dx.doi.org/10.2478/s13533-012-0147-2

[8] Cornen, G., Bandet, Y., Giresse, P. and Maley, J. (1992) The Nature and Chronostratigraphy of Quaternary Pyroclastic Accumulations from Lake Barombi-Mbo (West Cameroon). Journal of Volcanology and Geothermal Research, 51, 357-374. http://dx.doi.org/10.1016/0377-0273(92)90108-P

[9] Aka, F.T. (2000) Noble Gas Systematics and K-Archronology: Implications for the Geochemical and Geotectonic Evolution of the Cameroon Volcanic Line, West Africa. Doctoral Thesis, Okayama University, Okayama.

[10] Tamen, J., Nkoumbou, C., Mouafo, L., Reusser, E. and Tchoua, F.M. (2007) Petrology and Geochemistry of Monogenetic Volcanoes of the Barombi Koto Volcanic Field (Kumba Graben, Cameroon Volcanic Line): Implications for Mantle Source Characteristics. ComptesRendus de Géosciences, 339, 799-809. http://dx.doi.org/10.1016/j.crte.2007.09.007

[11] Teitchou, M.I., Grégoire M., Dantas, C. and Tchoua F.M. (2007) The Upper Mantle Beneath the Kumba Plain (Cameroon Line), Documented by Spinel Peridotite Xenolith in Basaltic Lava. Comptes Rendus de Géosciences, 33, 101-109. (in French) Le manteau supérieur à l'aplomb de la plaine de Kumba (ligne du Cameroun), d'après les enclaves de péridotites à spinelles dans les laves basaltiques.Comptes Rendus de Géosciences, 33, 101-109. http://dx.doi.org/10.1016/j.crte.2006.12.006

[12] Dumort, J.-C. (1968) Carte Géologique et Notice explicative sur la feuille Douala-ouest et carte géologique de reconnaissance au 1:500,000. Dir. Mines etGéologie Cameroun. BRGM, Paris.

[13] Yagi (2006) Manual Mineral Separation for K-Ar Dating Hikaru. Geotechnical, Founding Preparation (Hiruzen Geochronology Institute 10th Anniversary Commemorative Special), 19-25. (in Japanese)

[14] Nagao, K., Nishi, K., Si, Y. and Itaya, T. (1984) K-Ar Dating of Affiliates of the Ogata Only Pill. Okayama University Hiruzen Research Institute, 9, 19-38. (in Japanese) 
[15] Itaya, T., Nagao, K., Inoue, K., Honjou, Y., Okada, T. and Ogata, A. (1991) Argon Isotope Analysis by a Newly Developed Mass Spectrometric System for K-Ar Dating. Mineralogical Journal, 15, 203-221. http://dx.doi.org/10.2465/minerj.15.203

[16] Steiger, R.H. and Jäger, E. (1977) Subcommission on Geochronology: Convention on the Use of Decay Constants in Geo- and Cosmochronology. Earth and Planetary Science Letters, 26, 359-362. http://dx.doi.org/10.1016/0012-821X(77)90060-7

[17] Li, D., Chen, W. and Li, Q. (2000) K-Ar Age of Young Volcanic Rocks and Excess Argon. Chinese Science Bulletin, 45, 659-664. http://dx.doi.org/10.1007/BF02886046

[18] Maley, J., Livignstone, D.A., Giresse, P., Brenac, P., Kling, G., Stager, C., Thouveny, N., Kelts, K., Haag, M., Fournier, M., Bandet, Y., Williamson, D. and Zogning, A. (1991) West Cameroon Quaternary Lacustrine Deposits: Preliminary Results. Journal of African Earth Sciences (and the Middle East), 12, 147-157. http://dx.doi.org/10.1016/0899-5362(91)90065-7

[19] Valentine, G. (2012) Shallow Plumbing Systems for Small-Volume Basaltic Volcanoes, 2: Evidence from Crustal Xenoliths at Scoria Cones and Maars. Journal of Volcanology and Geothermal Research, 223-224, 47-63.

[20] Nemeth, K., Cronin, S.J., Haller. M.J., Brenna, M. and Csillag, G. (2010) Modern Analogues for Miocene to Pleistocene Alkali Basaltic Phreatomagmatic Fields in the Pannonian Basin: "Soft-Substrate” to "Combined” Aquifer Controlled Phreatomagmatism in Intraplate Volcanic Fields Research Article. Central European Journal of Geosciences, 2, 339-361.

[21] Lucas, Y. and Chawel, A. (1992) Soil Formation in Tropically Weathered Terrains. In: Butt, C.R.M. and Zeegers, H., Eds., Regolith Exploration Geochemistry in Tropical and Subtropical Terrains, Handbook of Exploration Geochemistry, Vol. 4, Elsevier, Amsterdam, 57-77. http://dx.doi.org/10.1016/B978-0-444-89095-5.50011-0

[22] KagouDongmo, A., Wandji, P., Pouclet, A., Vicat, J., Cheilletz, A., Nkouathio, D.G., Alexandrov, P. and Tchoua, F.M. (2001) Volcanological Evolution of the Mount Manengouba (Cameroon Line), New Petrographical, Geochemical, and Geochronological Data. ComptesRendus de l'Academie des Sciences Series IIA Earth and Planetary Science, 333, 155-162.

[23] Nkouathio, D.G., KagouDongmo, A., Bardintzeff, J.M., Wandji, P., Bellon, H. and Pouclet, A. (2008) Evolution of Volcanism in Graben and Horst Structures along the Cenozoic Cameroon Line (Africa): Implications for Tectonic Evolution and Mantle Source Composition. Mineralogy and Petrology, 94, 287-303. http://dx.doi.org/10.1007/s00710-008-0018-1

[24] Aka, F.T., Nagao, K., Kusakabe, M., Sumino, H., Tanyileke, G., Ateba, B. and Hell, J. (2004) Symmetrical Helium Isotope Distribution on the Cameroon Volcanic Line, West Africa. Chemical Geology, 203, 205-223. http://dx.doi.org/10.1016/j.chemgeo.2003.10.003. 
Scientific Research Publishing (SCIRP) is one of the largest Open Access journal publishers. It is currently publishing more than 200 open access, online, peer-reviewed journals covering a wide range of academic disciplines. SCIRP serves the worldwide academic communities and contributes to the progress and application of science with its publication.

Other selected journals from SCIRP are listed as below. Submit your manuscript to us via either submit@scirp.org or Online Submission Portal.
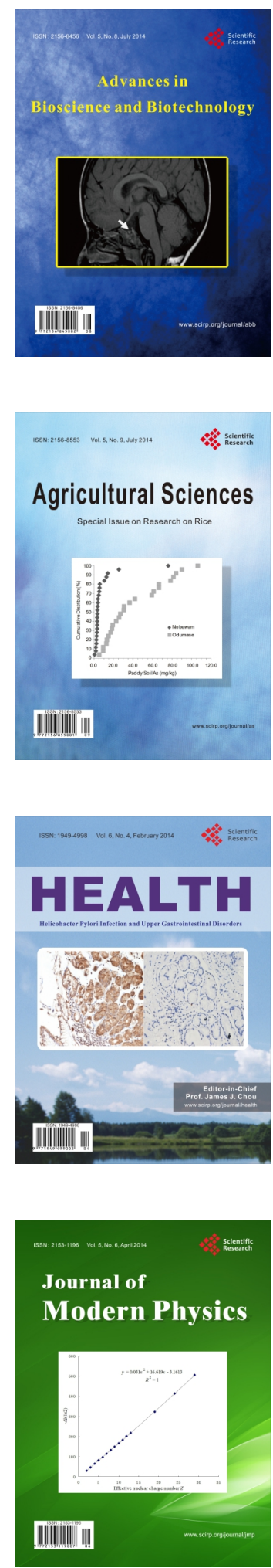
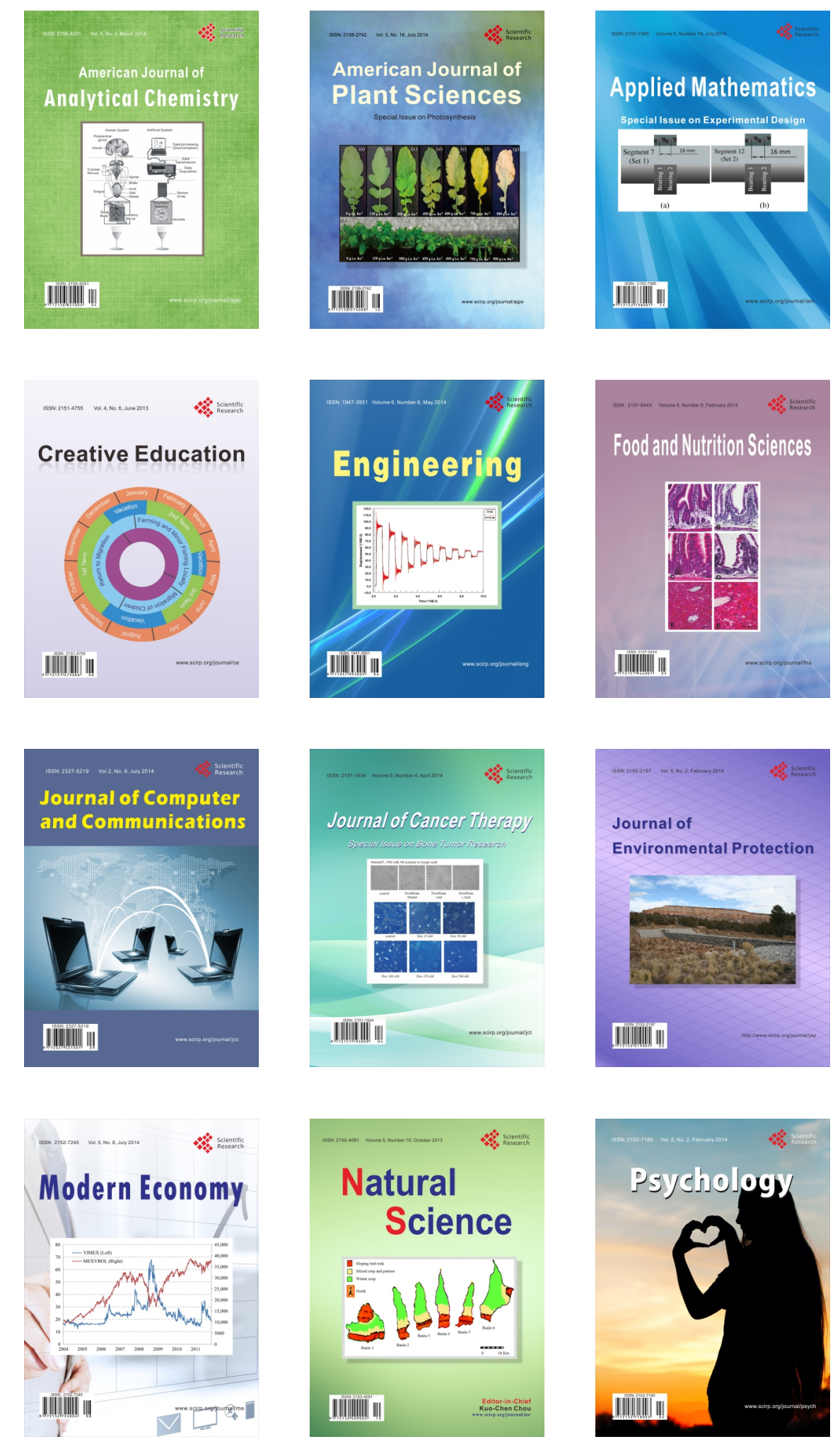